\title{
Tobramycin Sulfate
}

National Cancer Institute

\section{Source}

National Cancer Institute. Tobramycin Sulfate. NCI Thesaurus. Code C893.

The sulfate salt of tobramycin, an aminoglycoside antibiotic derived from the bacterium Streptomyces tenebrarius with bactericidal activity. Following active transport into the cell, tobramycin binds irreversibly to a specific aminoglycoside receptor on the bacterial $30 \mathrm{~S}$ ribosomal subunit and fixes the $30 \mathrm{~S}-50 \mathrm{~S}$ ribosomal complex at the start codon $(A \cup G)$, interfering with the initiation of protein synthesis. In addition, this agent induces misreading of the mRNA template, which results in 1) detachment of the ribosomal complex and inhibition of protein elongation or 2) incorporation of the incorrect amino acids into the growing polypeptide chain and the production of abnormal or nonfunctional proteins. Altogether, cell permeability is altered and cell death ensues. 